Syntax Literate : Jurnal Ilmiah Indonesia p-ISSN: 2541-0849

e-ISSN : 2548-1398

Vol. 5, No. 2 Februari 2020

\title{
UPAYA PENINGKATAN PEMAHAMAN KINEMATIKA GERAK ROTASI MELALUI MODEL PEMBELAJARAN EXPLICIT INTRUCTION DI KELAS XI-IPA 4 SMA NEGERI 9 KOTA CIREBON
}

\author{
Aris Supriyono \\ SMA Negeri 9 Kota Cirebon \\ Email: aris.supriyono21@gmail.com
}

\section{Abstract}

This research aims to improve the ability of students of the class XI-IPA 4 SMA Negeri 9 Cirebon City in understanding the interviewee's explanation in the physics subjects on the material "Rotational Motion Kinematics" with the application of The Learning Explicit Model Instruction, so learning physics becomes more fun and raises creativity. The problem that faced by the teacher is still a lack of students ability to understand material explanation of interviews, such as lack of ability of students to do the summation of rotation motion kinematics, explaining the equation of harmonic motion, analyzing motion rotation kinematics in the spring and penal swing, and observe the difference phase, phase angle, and different phases of rotation motion kinematics. Class Action Research (PTK) is implemented in the class XI-IPA 4 SMA Negeri 9 Cirebon City. The activities performed two cycles of action. In general, the procedures in each action are: (1) planning, (2) implementation, (3) observation, (4) reflection of the results of the research action and results indicating: Based on data analysis during cycle I and cycle II can be concluded that the application of Explicit Instruction Model Learning in physics learning on "vector" material has been increased in both qualitative and quantitative changes, i.e: Student learning outcomes in Physics Learning Show: 1) Preliminary results (pre-test) show an average score: 57.07. 2) results on the cycle I increased to average score: 66.56. 3) results on cycle II rose to average score: 83.63. Student learning activities in the physics learning activity on the material "Rotational Motion Kinematics" shows: 1) Improvement of students who can answer questions or problem, 2) Improvement of students who can express their opinions, 3) Enhancement of students who actively pay attention to, 4) students who ask questions or reveal problems sufficiently increased, 5) Students who work and study actively: a) in cycle I reached the average: $48 \%$ (good enough) b) on the Silus II reaches average: $80 \%$ (good). The results of the teacher performance observation in the physics learning process at each cycle are: 1) on the cycle I show an average of 49\% (good enough), 2) on cycle II rises and shows an average of $94 \%$ (excellent). Based on the explanation above it can be concluded that the action hypothesis is proven, by implementing an Explicit Instruction Learning Model can improve understanding and learning outcomes of physics in students Class XI-IPA 4 SMA Negeri 9 Cirebon City.

Keywords: Rotation Motion Kinematics, Explicit Intruction Learning 


\begin{abstract}
Abstrak
Penelitian ini bertujuan untuk meningkatkan kemampuan siswa kelas XI-IPA 4 SMA Negeri 9 Kota Cirebon dalam memahami Penjelasan Narasumber dalam mata pelajaran Fisika pada materi "Kinematika Gerak Rotasi" dengan penerapan Model Pembelajaran Explicit Intruction, sehingga pembelajaran Fisika menjadi lebih menyenangkan dan menimbulkan kreatifitas. Masalah yang dihadapi guru adalah masih kurangnya kemampuan siswa dalam memahami materi Penjelasan Narasumber, seperti kurangnya kemampuan siswa dalam melakukan penjumlahan Kinematika Gerak Rotasi, menjelaskan Persamaan gerak harmonik, menganalisa Kinematika Gerak Rotasi pada pegas dan ayunan bandul, dan mengamati perbedaan fase, sudut fase,dan beda fase pada Kinematika Gerak Rotasi. Penelitian Tindakan Kelas (PTK) ini dilaksanakan pada kelas XI-IPA 4 SMA Negeri 9 Kota Cirebon. Kegiatan dilakukan sebanyak dua siklus tindakan. Secara umum prosedur dalam setiap tindakan adalah: (1) perencanaan, (2) pelaksanaan, (3) observasi, (4) refleksi hasil penelitian tindakan dan hasilnya menunjukkan: berdasarkan analisis data selama Siklus I dan Siklus II dapat disimpulkan bahwa Penerapan Model Pembelajaran Pembelajaran Explicit Intruction dalam Pembelajaran Fisika pada Materi "Vektor" telah terjadi perubahan peningkatan baik secara kualitatif maupun kuantitatif, yaitu: Hasil belajar siswa dalam pembelajaran Fisika menunjukkan: 1) Hasil awal (Pra test) menunjukkan skor rata-rata: : 57.07. 2) Hasil pada siklus I naik menjadi skor rata-rata: 66.56. 3) Hasil pada siklus II naik menjadi skor rata-rata: 83.63. Aktivitas belajar siswa dalam kegiatan pembelajaran Fisika pada materi "Kinematika Gerak Rotasi" menunjukkan: 1) Siswa yang bisa menjawab pertanyaan atau permasalahan meningkat, 2) Siswa yang menyampaikan pendapat meningkat, 3) Siswa yang memperhatikan secara aktif meningkat, 4) Siswa yang mengajukan pertanyaan atau mengungkapkan permasalahan cukup meningkat, 5) Siwa yang bekerja dan belajar secara aktif: a) Pada siklus I mencapai rata-rata: $48 \%$ (cukup baik) b) Pada silus II mencapai rata-rata : 80 \% (baik). Hasil Observasi Kinerja Guru dalam proses pembelajaran Fisika pada setiap siklusnya yaitu: 1) Pada siklus I menunjukkan rata-rata 49 \% (cukup baik), 2) Pada siklus II naik, dan menunjukkan rata -rata $94 \%$ (baik sekali). Berdasarkan penjelasan di atas dapat disimpulkan bahwa hipotesis tindakan terbukti, yaitu dengan menerapkan Model Pembelajaran Explicit Intruction dapat meningkatkan Pemahaman dan hasil belajar Fisika pada siswa Kelas XI-IPA 4 SMA Negeri 9 Kota Cirebon.
\end{abstract}

Kata kunci: Kinematika Gerak Rotasi, Pembelajaran Explicit Intruction.

\title{
Pendahuluan
}

Fisika adalah mata pelajaran dengan rumus dan pembahasan yang relatif luas dan banyak. Karena alasan tersebut beberapa peserta didik cenderung malas dan enggan untuk belajar fisika. Namun demikian, sebagai pelajaran dianggap vital (Komalawati, 2017).

Fisika merupakan salah satu rumpun ilmu yang mempelajari tentang alam semesta. Kajian ilmu yang dibahas dalam Ilmu Fisika sangat luas. Banyak fenomena 
dan kejadian dalam kehidupan sehari-hari yang ditemukan dari pengaplikasian ilmuilmu fisika, baik beriupa fenomena alam ataupun rekayasa teknologi. Oleh karena itu fisika memilki tingkat urgensitas yang tinggi karena merupakan ilmu dasar untuk penguasaan teknologi masa depan (Indrajit, 2009). Ilmu Fisika merupakan ilmu yang berperan penting dalam kehidupan manusia. Ilmu fisika akan berguna bagi kehidupan manusia apabila sudah di wujudkan dalam bentuk hasil dan teknologi. Dengan ilmu fisika semua pekerjaan menjadi ringan karena adanya penerapan ilmu fisika yang di implikasikan dalam teknologi (Harefa, 2013). Tujuan Pembelajaran Fisika dalam kurikulum SMA adalah untuk memahami berbagai peristiwa alam yang ditemukan dalam kehidupan sehari-hari, mengetahui hakekat materi serta perubahannya, menanamkan metode ilmiah, mengembangkan kemampuan dalam mengajukan gagasangagasan.

Konsep Fisika yang disajikan pada SMA masih bersifat dasar, oleh karena itu belajar fisika sangat menarik bagi siswa jika penyajiannya bersifat kongkrit dan melibatkan siswa secara efektif, hal ini terjadi karena ilmu fisika berkembang berdasarkan hasil percobaan para ahli untuk menghasilkan fakta dan teoritis tentang materi yang kebenarannya dapat dijelaskan dengan logika fisika. Seperti yang diungkapkan oleh Suryono dalam proses pembelajaran fisika bukan hanya sekedar konsep menghafal tetapi dipahami serta dipraktikkan dalam kehidupan nyata, sehingga siswa mampu menguasai permasalahan yang dihadapinya.(Suryono, 2012)

Salah satu pokok bahasan dari pelajaran Fisika untuk SMA adalah "Kinematika Gerak Rotasi". Dengan menguasai pokok bahasan "Kinematika Gerak Rotasi”, siswa diharapkan dapat mempelajari pokok bahasan selanjutnya dengan mudah. Dalam memahami materi Pembelajaran diperlukan suatu pemahaman konsep.

Berdasarkan hasil keterangan yang diperoleh bahwa rata-rata nilai Hasil belajar fisika masih dibawah standar. Kriteria Ketuntasan Minimal (KKM) yang ditentukan di Kelas XI- IPA 4 SMA Negeri 9 Kota Cirebon yaitu 75. Berdasarkan permasalahan yang telah diuraikan perlu kiranya diadakan suatu penelitian tindakan kelas. Dengan menerapkan sebuah strategi pembelajaran yang lebih memberdayakan siswa, yaitu suatu pendekatan pembelajaran yang mampu meningkatkan minat dan motivasi siswa (Komalasari, 2010). Pendekatan pembelajaran ini salah satunya menekankan kepada bagaimana belajar di sekolah yang dikontekskan ke dalam situasi dunia nyata, sehingga hasil belajar dapat diterima dan berguna bagi siswa selama di sekolah atau setelah mereka lulus dari sekolah tersebut, pendekatan tersebut adalah Model Pembelajaran Explicit Intruction. Dengan penggunaan model ini diharapkan agar materi pelajaran PAI dapat mudah dipahami dan dapat meningkatkan motivasi serta prestasi belajar siswa terhadap mata pelajaran Fisika.

Model Pembelajaran Explicit Intruction, merupakan model pembelajaran langsung khusus dirancang untuk mengembangkan belajar siswa tentang pengetahuan proseduran dan pengetahuan deklaratif. Pengetahuan Deklaratif, yaitu pengetahuan yang bisa dideklarasikan biasanya dalam bentuk kata atau singkatnya pengetahuan konseptual. Pengetahuan Prosedural, yaitu pengetahuan tentang tahapan yang harus dilakukan 
misalnya dalam hal pembagian satu bilangan ataupun cara kita mengemudikan sepeda, singkatnya "pengetahuan bagaimana" yang dapat diajarkan dengan pola selangkah demi selangkah. Selain itu model ini sangat cocok diterapkan pada materi yang memerlukan demonstrasi seperti mata pelajaran Fisika.

Dengan demikian Model Pembelajaran Explicit Intruction patut dicobakan untuk meningkatkan prestasi belajar siswa di SMA Negeri 9 Kota Cirebon pada mata pelajaran Fisika kelas XI-IPA 4 Semester 2 tahun 2017 pada materi "Gerak Rotasi Kesetimbangan Tegar”, yang sebelumnya menunjukan prestasi rendah.

\section{Metode Penelitian}

\section{Prosedur Penelitian}

Prosedur pelaksanaan Penelitian Tindakan Kelas (PTK) terlebih dahulu dimulai dengan melakukan perencanaan lalu dilanjutkan dengan pelaksaan tindakan, pengamatan / observasi dan refleksi (Arikunto \& Suhardjono, 2006). Penelitian tindakan kelas dilakukan dengan dua siklus, dan tiap siklus dilaksanakan sesuai dengan perubahan yang dicapai, sesuai desain faktor yang diteliti, Untuk mengetahui efektifitas Pembelajaran Fisika pada materi "Gerak Harmonk sederhana" di Kelas XI- IPA 4 SMA Negeri 9 Kota Cirebon dilakukan observasi terhadap kegiatan Pembelajaran yang dilakukan oleh guru, dan diadakan wawancara baik dengan guru maupun siswa. Melalui kegiatan ini dapat dilakukan musyawarah antara guru dengan observer untuk menetapkan tindakan paling tepat dalam rangka meningkatkan efektifitas Pembelajaran di Kelas XI- IPA 4. Hasil wawancara guru kelas, langkah yang paling tepat adalah meningkatkan aktivitas dan peran serta siswa dalam proses Pembelajaran tersebut dengan melaltih dan mengembangkan keterampilan intelektual siswa.

Dengan berpatokan pada refleksi awal tersebut, maka prosedur pelaksanaan penelitian tindakan kelas ini meliputi: (1) perencanaan, (2) pelaksanaan tindakan, (3) observer, (4) refeleksi dalam setiap siklus.

Penjelasan pelaksanaan penelitian tindakan kelas tersebut dapat disajikan melalui table berikut:

Tabel 1 Prosedur Pelaksanaan Peneliutian Tindakan Kelas (PTK)

\begin{tabular}{|c|c|c|}
\hline Siklus & $\begin{array}{l}\text { Prosedur } \\
\text { Penelitian }\end{array}$ & Uraian Permasalahan Ptk \\
\hline $\mathbf{I}$ & Perencanaan awal & $\begin{array}{l}\text { Pengamatan langsung proses Pembelajaran di kelas, diskusi } \\
\text { tim peneliti tentang masalah yang terjadi di kelas, merumuskan } \\
\text { masalah yang terjadi, mengidentifikasi permasalahan pokok, } \\
\text { dan menyusun hipotesis pemecahan }\end{array}$ \\
\hline $\mathbf{F}$ & $\begin{array}{l}\text { Perencanaan } \\
\text { identifikasi masalah } \\
\text { dan penetapan } \\
\text { alternative } \\
\text { pemecahan masalah }\end{array}$ & $\begin{array}{l}\text { 1) Merencanakan Pembelajaran yang akan diterapkan dengan } \\
\text { menerapkan Model Pembelajaran Explicit Intruction } \\
\text { dalam PBM. } \\
\text { 2) Peneliti menyusun silabus yang berkaitan dengan materi } \\
\text { "Kinematika Gerak Rotasi" pada mata pelajaran Fisika. } \\
\text { 3) Mengembangkan skenario Pembelajaran. } \\
\text { 4) Menyusun LKM }\end{array}$ \\
\hline
\end{tabular}


5) Menyiapkan sumber belajar

6) Mengembangkan format evaluasi

7) Mengembangkan format obsevasi Pembelajaran

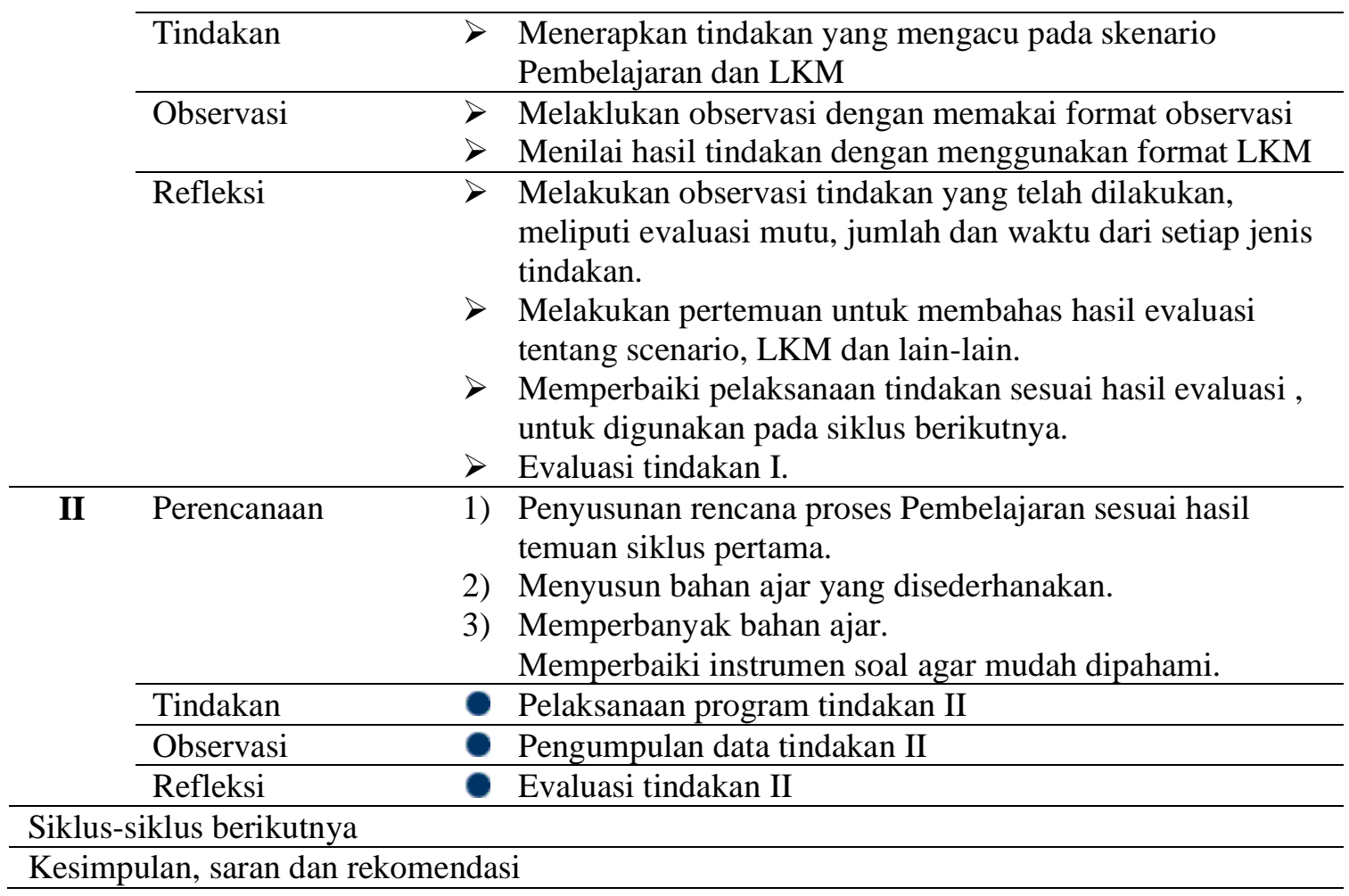

Untuk memperjelas tentang prosedur penelitian tersebut dapat dikemukakan melalui diagram berikut. 


\section{Gambar 2 \\ Diagram Prosedur Penelitian}
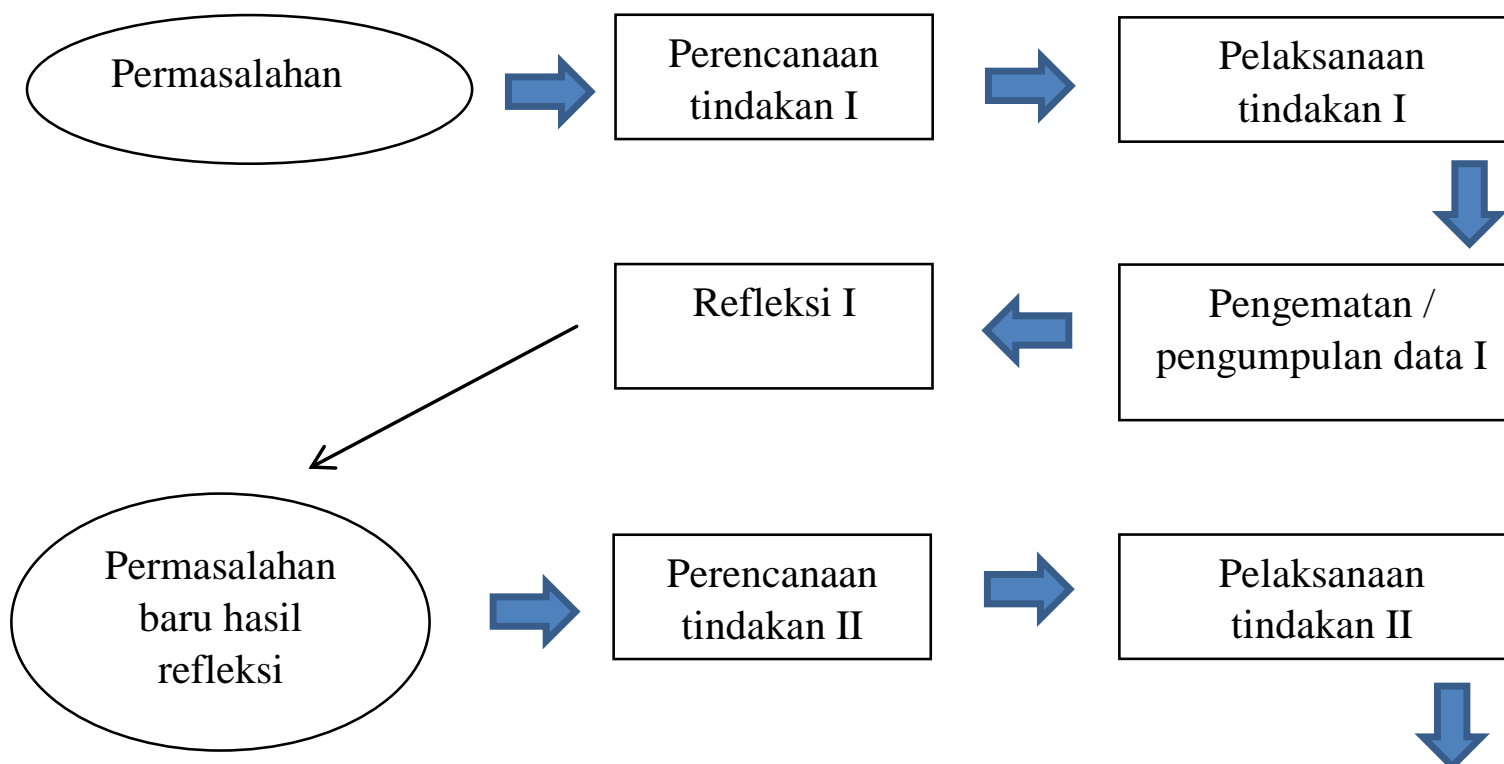

Pengematan / pengumpulan data I

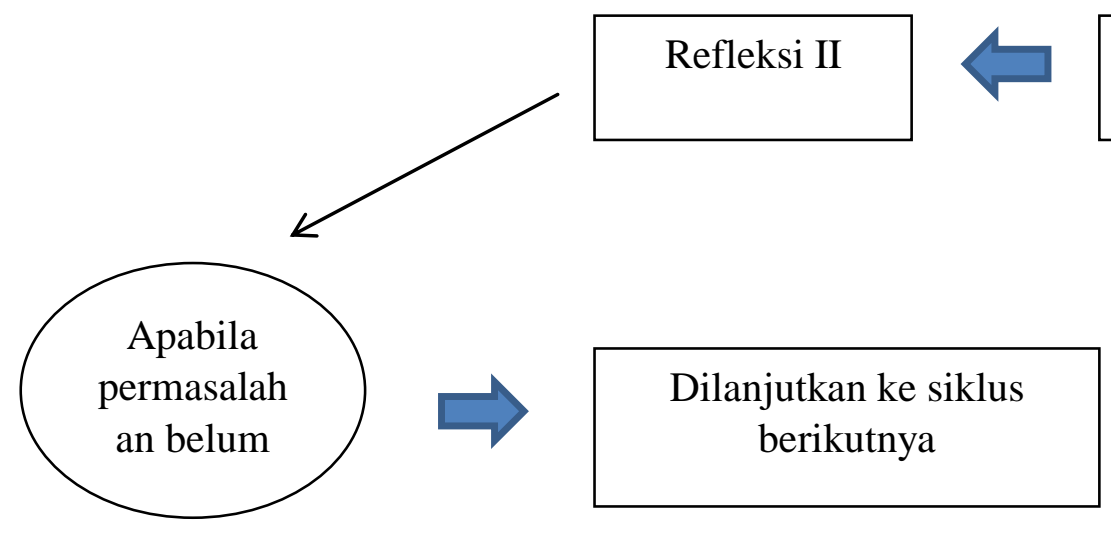

Pengamatan / pengumpulan data II

\section{Instrumen Penelitian}

Instrumen penelitian tindakan kelas ini adalah:

a. Tes Tertulis

Tes tertulis digunakan untuk mengumpulkan data tentang kemampuan siswa dalam menguasai materi yang diajarkan. Dan test tertulis ini dirancang oleh peneliti sesuai dengan tujuan yang telah tertuang di dalam kisi-kisi soal.

b. Observasi

Teknik observasi untuk memperoleh data tentang pemahaman urutan perilaku siswa dengan lengkap meliputi:

1) Suasana kelas

2) Perilaku masing-masing siswa saat mengikuti Pembelajaran di dalam kelas. 
Teknik ini dipergunakan hanya untuk mengumpulkan data dan bukan untuk mentafsirkan data

\section{Analisis Data}

Data yang dianalisis dalam penelitian tindakan kelas ini adalah:

a. Data kualitatif digunakan untuk memberikan deskripsi tentang pandangan dan pendapat dari subyek penelitian

b. Data kuantitatif digunakan dengan cara mencatat peristiwa hasil prestasi belajar siswa sebelum adanya penelitian, kemudian diadakannya penelitian tindakan kelas pada siklus pertama dan kedua.

Dengan pengelompokan data, maka akan ditemukan nilai rendah dan nilai tinggi serta ditemukan nilai rata-rata dari sebelum adanya penelitian tindakan kelas, ketika diadakan dan ada perbaikan.

\section{Indikator Kinerja (Kriteria Keberhasilan Tindakan)}

Kriteria keberhasilan siswa sesuai dengan tujuan akhir penelitian ini yaitu dikelompokkan ke dalam kategori, dengan kriteria sebagai berikut:

$$
\begin{aligned}
90-99 & : \text { Sangat baik } \\
60-89 & : \text { Baik } \\
40-59 & : \text { Cukup } \\
20-39 & : \text { Kurang } \\
0-19 & \text { : Sangat Kurang }
\end{aligned}
$$

Berdasarkan indikator keberhasilan di atas peneliti menetapkan criteria dalam penelitian ini baik $(60-89)$. Adapun yang menjadi indikator keberhasilan tindakan kelas ini adalah jika terjadi perubahan peningkatan motivasi, minat dan kesadaran siswa dalam belajar di sekolah melalui Pembelajaran dengan Model Pembelajaran Explicit Intruction. Secara kuantitatif dapat diindikasikan jika $70 \%$. Dari seluruh siswa terlibat pemahaman terhadap materi layanan berubah lebih baik. Hal ini diwujudkan dengan adanya kemampuan siswa $70 \%$ dalam menjawab soal pilihan ganda dengan benar. Disamping itu juga $75 \%$ siswa terlibat aktif dalam pembelajaran dengan Model Pembelajaran Explicit Intruction. Kemampuan guru untuk mengimplementasikan penerapan Model Pembelajaran tersebut dapat terlaksana dengan baik.

\section{Hasil dan Pembahasan}

\section{A. Hasil Penelitian}

Penerapan Model Pembelajaran Explicit Intruction dalam pembelajaran Fisika pada materi "Kinematika Gerak Rotasi” di Kelas XI- IPA 4 SMA Negeri 9 Kota Cirebon melalui penelitian tindakan kelas (PTK) dikakukan 2 siklus, masingmasing siklus terdiri dari studi pendahuluan, perencanaan, tindakan, observer dan refleksi kegiatan yang dilaksanakan.

Pada awal pembelajaran guru memberikan motivasi yang menuntun siswa untuk mengingat kembali materi yang akan dibahas, memberikan motivasi kepada 
siswa agar ikut aktif berperan serta dalam proses belajar, serta menginformasikan tentang kompetensi yang harus dikuasai.

\section{Siklus Pertama ( I )}

Siklus pertama dilakukan: a) identifikasi permasalahan menyangkut bahan pelajaran yang digunakan, strategi pembelajaran yang biasa digunakan. Pada siklus ini menggunakan pendekatan konvensional, b). menyajikan materi pembelajaran "Kinematika Gerak Rotasi", c). melakukan pengamatan dengan menggunakan observasi dan pemotretan, d). mengukur dampak pendekatan konvensional digunakan daftar aktivitas siswa.

\section{a. Studi Pendahuluan}

Dalam studi pendahuluan umumnya menggunakan pembelajaran konvensional. Pembelajaran meliputi metode ceramah, tanya jawab dan memberikan tugas. Guru menjelaskan materi pembelajaran di Kelas XI- IPA 4 SMA Negeri 9 Kota Cirebon.

\section{b. Perencanaan}

Peneliti mengadakan kolaborasi dengan guru lain guna menyusun rencana penelitian, yang meliputi: 1) tujuan pembelajaran, 2) kompetensi dan materi pembelajaran, 3) strategi pembelajaran berupa Model dan media yang digunakan, serta sumber belajar dan 4) evaluasi hasil belajar.

\section{c. Tindakan}

\section{1) Kegiatan Pendahuluan (20 menit)}

a. Guru membuka pembelajaran dan mengucap salam.

b. Guru mengabsen

c. Guru membagi kelompok belajar.

d. Guru memotivasi siswa dan memberikan pertanyaan: "Sebuah roda berjari-jaria $10 \mathrm{~cm}$ berotasi dengan sudut rotasi yang dinyatakan dengan persamaan $\theta=\left(4 \mathrm{rad} / \mathrm{s}^{2}\right) \mathrm{t}^{2}$.

Siapa yang dapat menentukan:

- Besar sudut $\theta$ pada waktu $\mathrm{t}_{1}$ ?

- Jarak tempuh partikel pada tepi roda selama interval waktu $t_{1}$ dan $t_{2}$ ?

\section{2) Kegiatan Inti (90 menit) :}

a. Guru menjelaskan tentang metode yang diterapkan dalam mata pelajaran Fisika kepada siswa yaitu dengan Model Pembelajaran Explicit Intruction.

b. Guru membagi kelompok belajar menjadi 6 kelompok,

c. Guru membagi siswa untuk berpasangan.

d. Guru memberikan arahan bahwa siswa bertanggung jawab atas segala sesuatu di dalam kelompoknya, seperti milik mereka sendiri,

e. Guru menjelaskan materi pembelajaran tentang "Kinematika Gerak Rotasi”. 
f. Guru membagi wacana. Materi tiap siswa untuk dibaca dan membuat ringkasan.

g. Siswa membagi tugas dan tanggung jawab yang sama di antara anggota kelompoknya,

h. Siswa mengerjakan tugas yang diberikan guru pada lembar kerja.

i. Guru dan siswa menetapkan siapa yang pertama berperan sebagai pembicara dan siapa yang berperan sebagai pendengar.

j. Siswa mempresentasikan/membacakan hasil kerja kelompok di depan kelas,

k. Pembicara (siswa) membacakan ringkasannya selengkap mungkin, dengan memasukkan ide-ide pokok dalam ringkasannya

1. Pendengar (siswa) dari kelompok lain:

Menyimak/ mengoreksi/ menunjukkan ide-ide pokok yang kurang lengkap.

Membantu, mengingat/ menghapal ide-ide pokok dengan menghubungkan materi sebelumnya atau dengan materi lainnya.

m. Guru bersama siswa memberi kesimpulan hasil kerja kelompok.

\section{3) Kegiatan Penutup (15 menit)}

a. Guru memberikan evaluasi post test.

b. Memberikan penghargaan kepada siswa dengan kinerja baik

c. Guru menyuruh siswa merangkum materi "Kinematika Gerak Rotasi".

d. Guru memberikan tugas dan latihan PR.

\section{d. Observasi}

1. Observasi terhadap data kinerja siswa dalam proses perbaikan pembelajaran, seperti:

a) Siswa yang mengajukan pertanyaan/ permasalahan.

b) Siswa yang mampu menjawab pertanyaan.

c) Siswa yang mampu menyampaikan pendapat

d) Siswa yang memperhatikan materi pembelajaran secara aktif.

e) Siswa yang bekerja kelompok (dalam diskusi) secara aktif.

Hasilnya dapat dilihat pada tabel berikut.

Tabel 3

Hasil Observasi Kinerja Siswa dalam Proses Pembelajaran Siklus I

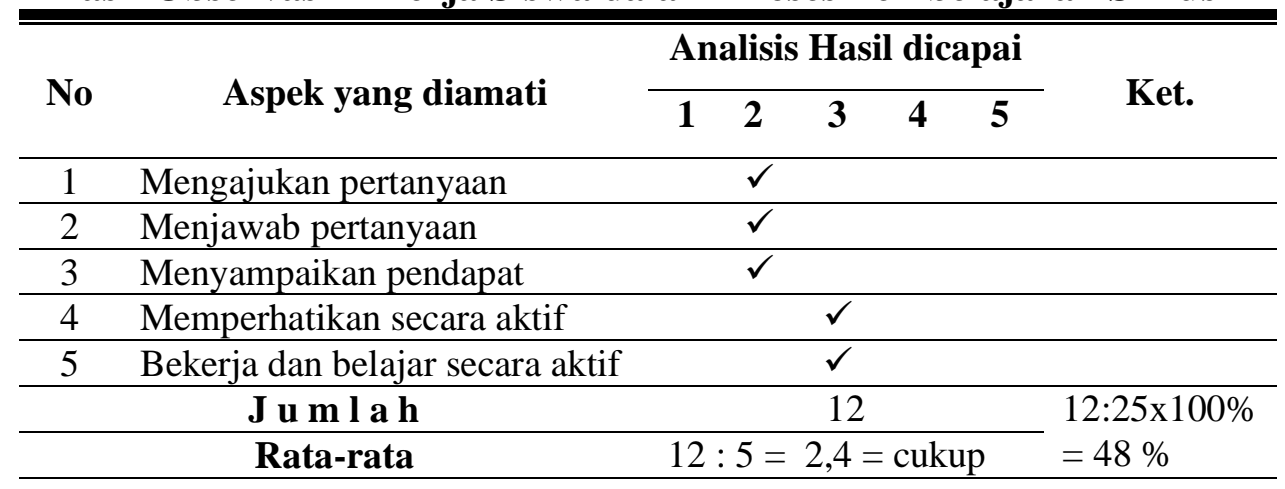


Dari hasil table diatas dapat disimpulkan bahwa perhatian siswa dalam Kegiatan Belajar Mengajar (KBM), keberanian, jawaban siswa, kesungguhan dalam mengikuti pelajaran, keseriusan mengerjakan soal ringan dan berat dinilai observer adalah Cukup ( C ).

Berdasarkan hasil pengamatan dari observer, bahwa bahwa kegiatan pembelajaran Fisika pada materi "Kinematika Gerak Rotasi" di Kelas XI-IPA 4 SMA Negeri 9 Kota Cirebon dengan menerapkan Model Pembelajaran Explicit Intruction, dinilai rata-rata cukup $(2,4)$.

\section{e. Refleksi Siklus I}

Pada siklus I kegiatan pembelajaran Fisika dengan menerapkan Model Pembelajaran Explicit Intruction masih banyak siswa yang tidak memanfaatkan waktu proses berkelompok dengan sebaik-baiknya. Masih banyak siswa yang tidak serius waktu proses pembelajaran sehingga hasil yang diperoleh juga minimal. Pada saat diskusi juga terlihat banyak siswa yang kurang serius dan ngobrol sendiri. Saat presentasi banyak siswa yang kurang lancar berbicara didepan kelas, ini terjadi karena siswa tidak terbiasa berbicara di depan kelas, sehinnga siswa merasa malu dan canggung terhadap teman-teman yang lain.

Pada siklus I ini dapat diketahui kelebihan dan kekurangan menggunakan pembelajaran Model Pembelajaran Explicit Intruction. Kelebihan yang dapat dirasakan siswa adalah siswa dapat membangun ingatannya sendiri karena siswa melihat dan mendengarkan sendiri apa yang dipelajarinya sehingga apa yang dilihat dan yang didengarkan melalui melalui alat visual akan masuk dalam ingatan siswa lebih lama, daripada mereka harus menghafalkan materi sesuai dengan buku. Sedang kekurangannya adalah banyak waktu yang terbuang, karena banyak siswa yang tidak serius dalam melakukan penelitian, Waktu berdiskusi digunakan untuk ngobrol dan bermain sendiri dan masih malu untuk presentasi didepan kelas.

Berdasarkan refleksi siklus I, langkah selanjutnya guru harus lebih memberikan motivasi kepada siswa agar dapat lebih serius ketika pelajaran sedang berlangsung, dan lebih percaya diri bila harus presentasi di depan kelas. Sehingga pada pelaksanaan siklus II hasil yang diperoleh menjadi lebih baik dari siklus I.

\section{Siklus Kedua ( II )}

Penelitian pada siklus II dilakukan dengan: a) identifikasi permasalahan menyangkut bahan pelajaran yang digunakan, strategi pembelajaran yang biasa digunakan, b). menyajikan materi "Kinematika Gerak Rotasi", c). melakukan pengamatan dengan menggunakan observasi dan pemotretan sebagai evaluasi pembelajaran.

\section{a. Studi Pendahuluan}


Guru menjelaskan materi lanjutan dari siklus I dan menanggapi isi laporan di Kelas II , dan materi tersebut dapat dilihat melalui table berikut.

\section{Tabel 4}

\section{Materi Pembelajaran Fisika Siklus II}

\begin{tabular}{lll}
\hline \hline No & \multicolumn{1}{c}{ Materi Pembelajaran } & \multicolumn{1}{c}{ Kompetensi Dasar } \\
\hline 1 & $\begin{array}{l}\text { Kinematika Gerak Rotasi, meliputi: } \\
\text { a. } \begin{array}{l}\text { Posisi sudut dalamgerak rotasi } \\
\text { b. Kecepatan sudut rata-rata dalam gerak } \\
\end{array}\end{array}$ & $\begin{array}{l}\text { Memformulasikan hubungan } \\
\text { antara konsep torsi, } \\
\text { momentum sudut, dan momen } \\
\text { inersia, berdasarkan hukum II }\end{array}$ \\
& c. Kecepatan sudut sesaar dalam gerak & Newton serta penerapannya \\
& rotasi & dalam masalah benda tegar \\
& d. Percepata sudut dalam gerak rotasi & \\
& e. Gerak Rotasi dengan Kecepatan Sudut & \\
\hline 2 & Kenstan & \\
\hline
\end{tabular}

\section{b. Perencanaan}

Peneliti mengadakan kolaborasi dengan guru lain dalam menyusun rencana penelitian, yang meliputi: 1) tujuan pembelajaran, 2) kompetensi dan materi pembelajaran, 3) strategi pembelajaran berupa metode dan media yang digunakan serta sumber belajar, dan 4) evaluasi hasil belajar

\section{c. Tindakan Kelas}

Langkah yang digunakan pada siklus ini adalah guru melakukan kegiatan pembelajaran sesuai deengan rencana pelaksanaan pembelajaran (RPP) yang meliputi kegiatan pendahuluan, kegiatan inti dan kegiatan penutup.

\section{Kegiatan Pendahuluan (20 menit)}

a. Guru membuka pembelajaran dan mengucap salam.

b. Guru mengabsen

c. Guru membagi kelompok belajar.

d. Guru memotivasi siswa dan memberikan pertanyaan: "Sebuah roda berjari-jari $10 \mathrm{~cm}$, berotasi dengan sudut rotasi yang dinyatakan dengan persamaan $\theta=\left(4 \mathrm{rad} / \mathrm{s}^{2}\right) \mathrm{t}^{2}$.

Siapa yang dapat menentukan:

- Kecepatan sudut rata-rata dalam satuan $\mathrm{rad} / \mathrm{s}$ antara $\mathrm{t}_{1}$ dan $\mathrm{t}_{2}$ ?

- Kecepatan sudut sesaat pada $\mathrm{t}=3 \mathrm{~s}$ ?

\section{Kegiatan Inti (90 menit) :}

a. Guru menjelaskan tentang metode yang diterapkan dalam mata pelajaran Fisika kepada siswa yaitu dengan Model Pembelajaran Explicit Intruction.

b. Guru membagi kelompok belajar menjadi 6 kelompok,

c. Guru membagi siswa untuk berpasangan.

d. Guru memberikan arahan bahwa siswa bertanggung jawab atas segala sesuatu di dalam kelompoknya, seperti milik mereka sendiri, 
e. Guru menjelaskan materi pembelajaran tentang "Kinematika Gerak Rotasi".

f. Guru membagi wacana. Materi tiap siswa untuk dibaca dan membuat ringkasan.

g. Siswa membagi tugas dan tanggung jawab yang sama di antara anggota kelompoknya,

h. Siswa mengerjakan tugas yang diberikan guru pada lembar kerja.

i. Guru dan siswa menetapkan siapa yang pertama berperan sebagai pembicara dan siapa yang berperan sebagai pendengar.

j. Siswa mempresentasikan/membacakan hasil kerja kelompok di depan kelas,

k. Pembicara (siswa) membacakan ringkasannya selengkap mungkin, dengan memasukkan ide-ide pokok dalam ringkasannya, Pendengar (siswa) dari kelompok lain:

(1) Menyimak/ mengoreksi/ menunjukkan ide-ide pokok yang kurang lengkap.

(2) Membantu, mengingat/ menghapal ide-ide pokok dengan menghubungkan materi sebelumnya atau dengan materi lainnya.

(3) Guru bersama siswa memberi kesimpulan hasil kerja kelompok.

\section{Kegiatan Penutup (15 menit)}

a. Guru memberikan evaluasi post test.

b. Memberikan penghargaan kepada siswa dengan kinerja baik

c. Guru menyuruh siswa merangkum materi "Kinematika Gerak Rotasi ".

d. Guru memberikan tugas dan latihan PR.

\section{d. Observasi}

1) Observasi terhadap data kinerja siswa dalam proses perbaikan pembelajaran, seperti:

a) Siswa yang mengajukan pertanyaan/ permasalahan.

b) Siswa yang mampu menjawab pertanyaan.

c) Siswa yang mampu menyampaikan pendapat

d) Siswa yang memperhatikan materi pembelajaran secara aktif.

e) Siswa yang bekerja kelompok (dalam diskusi) secara aktif.

Hasilnya dapat dilihat pada tabel berikut:

Tabel 5

Hasil Observasi Kinerja Siswa dalam Pembelajaran Siklus II

\begin{tabular}{|c|c|c|c|c|c|c|c|}
\hline \multirow[t]{2}{*}{ No } & \multirow{2}{*}{ Aspek yang diamati } & \multicolumn{5}{|c|}{$\begin{array}{c}\text { Analisis Hasil } \\
\text { dicapai }\end{array}$} & \multirow{2}{*}{ Ket. } \\
\hline & & 1 & 2 & 3 & 4 & 5 & \\
\hline 1 & Mengajukan pertanyaan/masalah & & & & $\checkmark$ & & \\
\hline 2 & Menjawab pertanyaan & & & & $\checkmark$ & & \\
\hline 3 & Menyampaikan pendapat & & & & $\checkmark$ & & \\
\hline 4 & Memperhatikan secara aktif & & & & $\checkmark$ & & \\
\hline 5 & Bekerja dan belajar secara aktif & & & & $\checkmark$ & & \\
\hline
\end{tabular}




\begin{tabular}{lll}
\hline J u m l a h & \multicolumn{1}{c}{20} & $\begin{array}{l}20: 25 \times 100 \% \\
=80 \%\end{array}$ \\
\hline Rata-rata & $\begin{array}{l}20: 5=4=\text { Baik } \\
\text { Sekali }\end{array}$ & \\
\hline
\end{tabular}

Dari hasil table diatas dapat disimpulkan bahwa perhatian siswa dalam KBM, keberanian, jawaban siswa, kesungguhan dalam mengikuti pelajaran, keseriusan mengerjakan soal ringan dan berat dinilai observer baik (B) kesanggupan, jawaban dan keberanian siswa dinilai sangat baik (B).

2) Observasi terhadap data kinerja guru dalam kegiatan proses perbaikan pembelajaran, yaitu dapat dilihat pada table berikut.

\section{Hasil Observasi Kinerja Guru dalam Pembelajaran Siklus II}

\begin{tabular}{|c|c|c|c|c|c|c|c|c|}
\hline \multirow{2}{*}{ No } & \multirow{2}{*}{ Aspek yang Dinilai } & \multirow{2}{*}{ 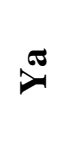 } & \multirow{2}{*}{$\frac{\sqrt{\sigma}}{\tilde{\sigma}}$} & \multicolumn{5}{|c|}{ Penilaian } \\
\hline & & & & 1 & 2 & 3 & 4 & 5 \\
\hline \multirow[t]{5}{*}{ A. } & Pengamatan Kegiatan Belajar Mengajar & & & & & & & \\
\hline & 1. Kegiatan Awal & & & & & & & \\
\hline & $\begin{array}{l}\text { a. Mengaitkan materi sekarang dengan } \\
\text { yang lalu }\end{array}$ & $\checkmark$ & - & & & & & $\checkmark$ \\
\hline & b. Menyampaikan tujuan pembelajaran & $\checkmark$ & - & & & & $\checkmark$ & \\
\hline & c. Memotivasi siswa & $\checkmark$ & - & & & & $\checkmark$ & \\
\hline
\end{tabular}

\section{Kegiatan Inti}

\begin{tabular}{llll}
\hline a. Mempresentasikan informasi & $\checkmark$ & - & $\checkmark$ \\
\hline b. Mengorganisasikan siswa & $\checkmark$ & - & $\checkmark$ \\
\hline c. Membimbing siswa & $\checkmark$ & - & $\checkmark$ \\
\hline 1) Diskusi kelompok & $\checkmark$ & - & $\checkmark$ \\
\hline 2) Mengajukan pertanyaan & $\checkmark$ & - & $\checkmark$ \\
\hline 3) Menjawab / menanggapi pertanyaan & $\checkmark$ & - & $\checkmark$ \\
\hline 4) Menyampaikan ide / pendapat & $\checkmark$ & - & \\
\hline 5) Memperhatikan secara aktif & $\checkmark$ & - & $\checkmark$ \\
\hline 6) Bekerja dan belajar bersama & $\checkmark$ & - & $\checkmark$ \\
\hline d. Memberikan test/ evaluasi & $\checkmark$ & - & \\
\hline e. Memberikan pengakuan/penghargaan & $\checkmark$ & - & $\checkmark$ \\
\hline f. Menggunakan alat peraga & $\checkmark$ & - & $\checkmark$ \\
\hline Keglatan Akhir
\end{tabular}

\section{Kegiatan Akhir}

a. Membimbing siswa untuk merangkum

b. Memberikan PR sebagai pengayaan

\section{B. Suasana Kelas}

\begin{tabular}{llll} 
1. Siswa antusias & $\checkmark$ & - & $\checkmark$ \\
\hline 2. Guru antusias & $\checkmark$ & - & $\checkmark$ \\
\hline 3. Waktu sesuai dengan alokasi & $\checkmark$ & - & $\checkmark$ \\
\hline 4. KBM sesuai dengan RPP & $\checkmark$ & - & $94: 100 \times 100 \%=94 \%$ \\
\hline J u m l a h & & $94: 20=4,7=$ baik sekali
\end{tabular}

Berdasarkan hasil pengamatan dari observer, bahwa bahwa kegiatan pembelajaran Fisika pada materi "Kinematika Gerak Rotasi" di Kelas XI- 
IPA 4 SMA Negeri 9 Kota Cirebon dengan menerapkan Model Pembelajaran Explicit Intruction pada siklus II dapat dikategorikan Baik Sekali.

\section{e. Refleksi}

Dari hasil observasi terhadap terhadap aktivitas siswa dalam mengikuti kegiatan proses perbaikan pembelajaran, seperti: siswa mengajukan pertanyaan/ permasalahan, siswa yang mampu menjawab pertanyaan, siswa yang mampu menyampaikan pendapat, siswa yang secara aktif memperhatikan materi pembelajaran, dan siswa yang secara aktif mengikuti kerja kelompok (diskusi) menunjukkan kategori baik, artinya penerapan Model Pembelajaran Explicit Intruction dalam pembelajaran Fisika pada materi "Sistem Tata Surya" diterima dengan oleh siswa dengan penuh antusias, sehingga dapat membangkitkan gairah belajar siswa.

Dampak dari-dari penerapan Model Pembelajaran Explicit Intruction dalam pembelajaran Fisika pada materi "Kinematika Gerak Rotasi" adalah hasil belajar diperolehnya peningkatan yang cukup signifikan hal ini dapat dilihat pada hasil pembasan berikut ini:

\section{A. Hasil Pembahasan}

Setelah selesai memberikan tindakan dari setiap siklusnya dapat dilihat adanya perubahan hasil belajar, yaitu hasil belajar siswa meningkat dari satu siklus I hingga ke siklus II yang cukup signifikan.

\section{Perolehan Hasil Belajar Siswa pada siklus I dan Siklus II}

Dari kegiatan pembelajaran Fisika pada materi "Kinematika Gerak Rotasi" dengan menerapkan Model Pembelajaran Explicit Intruction di kelas XI-IPA 4 SMA Negeri 9 Kota Cirebon diperoleh hasil belajar siswa pada tiap siklusnya mengalami peningkatan, yaitu dapat dilihat pada table berikut.

Tabel 7

Nilai Evaluasi Belajar Fisika Siswa Kelas XI-IPA 4 pada Setiap Siklus

\begin{tabular}{llcccc}
\hline \multirow{2}{*}{ No } & \multirow{2}{*}{ Nama Siswa } & \multirow{2}{*}{ L/P } & \multicolumn{3}{c}{ Nilai Hasil Belajar } \\
\cline { 5 - 6 } & & & Awal & Siklus I & SIklus II \\
\hline 1 & AGUNG JAYA FIRDAUS & L & 40 & 60 & 75 \\
\hline 2 & AMELIA AGUSTIN & $\mathrm{P}$ & 40 & 40 & 75 \\
\hline 3 & AMRUDIN & $\mathrm{L}$ & 50 & 50 & 80 \\
\hline 4 & ANGGA NADIANSAH & $\mathrm{P}$ & 60 & 50 & 85 \\
\hline 5 & DHEA RAHMA AYU & $\mathrm{P}$ & 40 & 50 & 85 \\
\hline 6 & DIMAS PRAYOGI & $\mathrm{L}$ & 45 & 50 & 85 \\
\hline 7 & DINDA NUR FADILAH & $\mathbf{P}$ & 40 & 60 & 85 \\
\hline 8 & DODI BILHAQQI WIGUNO & $\mathrm{L}$ & 60 & 80 & 85 \\
\hline 9 & EVI ERVIANA & $\mathrm{P}$ & 60 & 75 & 85 \\
\hline 10 & HIKMATUL AMALIA & $\mathrm{P}$ & 50 & 55 & 65 \\
\hline 11 & INTAN SUCI HATI & $\mathrm{P}$ & 70 & 80 & 80 \\
\hline 12 & JIHAN FIRDAUS SALAM & L & 50 & 60 & 80 \\
\hline
\end{tabular}




\begin{tabular}{|c|c|c|c|c|c|}
\hline 13 & JOHAN WAHYUDI & $\mathbf{L}$ & 70 & 80 & 80 \\
\hline 14 & LIDIAWATI & $\mathrm{P}$ & 40 & 70 & 80 \\
\hline 15 & MASHURI & $\mathrm{L}$ & 40 & 70 & 90 \\
\hline 16 & MEGA ANUGRAH RAHAYU & $\mathbf{P}$ & 60 & 70 & 80 \\
\hline 17 & MELA SANTIKA & $\mathrm{P}$ & 60 & 60 & 80 \\
\hline 18 & MILCHATUL MAULA & $\mathrm{P}$ & 40 & 50 & 85 \\
\hline 19 & MUHAMMAD HABIBI & $\mathrm{L}$ & 75 & 80 & 95 \\
\hline 20 & $\begin{array}{l}\text { MOCHAMMAD } \\
\text { FERNANDO }\end{array}$ & $\mathrm{L}$ & 50 & 60 & 75 \\
\hline 21 & NOK INDAH IRAWAN & $\mathrm{P}$ & 70 & 75 & 85 \\
\hline 22 & NUR FATIMAH & $\mathrm{P}$ & 70 & 80 & 90 \\
\hline 23 & $\begin{array}{l}\text { NURMA } \\
\text { PUTRI }\end{array}$ & $\mathrm{P}$ & 70 & 80 & 95 \\
\hline 24 & RODHOTUL JANNAH & $\mathrm{P}$ & 70 & 60 & 80 \\
\hline 25 & SHERLI OKTAVIANI & $\mathrm{P}$ & 70 & 75 & 90 \\
\hline 26 & SITI ULFAH & $\mathrm{P}$ & 75 & 80 & 95 \\
\hline 27 & SUSI SUSANTI & $\mathrm{P}$ & 40 & 70 & 80 \\
\hline 28 & THIO WAHYULIO PUTRA & $\mathrm{L}$ & 75 & 80 & 90 \\
\hline 29 & YUNI ALFINA & $\mathrm{P}$ & 75 & 80 & 90 \\
\hline \multicolumn{3}{|c|}{ Jumlah } & 1655 & 1930 & 2425 \\
\hline
\end{tabular}

Tingkat pencapaian penguasaan materi pembelajaran "Kinematika Gerak Rotasi" mengalami peningkatan pada awal sebelum tindakan mencapai rata-rata 57.07, dan setelah diadakan tindakan pada siklus I mencapai rata-rata 66,59 masih belum tuntas karena belum mencapai KKM, kemudian dilanjutkan pada siklus II hasilnya mencapai rata-rata 83.63 (sudah mencapai KKM).

\section{Perolehan hasil evaluasi belajar kelompok pada siklus I dan II}

Belajar kelompok diskusi pada proses perbaikan pembelajaran. setelah diadakan evaluasi diperoleh suatu hasil atau temuan, juga mengalami peningkatan hasil evaluasi pada tiap siklusnya hal ini dapat dilihat pada tabel berikut:

Tabel 8

Nilai Evaluasi Belajar Kelompok Siklus I dan II

\begin{tabular}{ccccc}
\hline \hline & & \multicolumn{2}{c}{ Nilai Evaluasi } & \\
\cline { 3 - 4 } No & Nama Kelompok & Siklus I & Siklus II & Keterangan \\
\hline 1 & I & 60 & 80 & Naik \\
\hline 2 & II & 70 & 90 & Naik \\
\hline 3 & III & 60 & 80 & Naik \\
\hline 4 & IV & 70 & 90 & Naik \\
\hline & Jumlah & 260 & 340 & \\
& Rata-rata & 65 & 85 & \\
\hline
\end{tabular}

Hasil evaluasi dari kerja kelompok dalam pembahasan materi "Kinematika Gerak Rotasi" pada siklus I memperoleh rata-rata 65 dan pada siklus II naik menjadi 85. 
Dari data hasil pembahasan secara kuantitatif terhadap hasil pretest dan post test siswa dalam belajar Fisika pada materi "Kinematika Gerak Rotasi" yaitu:

1. Hasil awal (Pra test) menunjukkan skor rata-rata: : 57.07.

2. Hasil pada siklus I naik menjadi skor rata-rata: 66.56 .

3. Hasil pada siklus II naik menjadi skor rata-rata: 83.63.

Dengan demikian, meningkatnya nilai dari hasil evaluasi pelajaran IPA pada materi "Kinematika Gerak Rotasi" pada tiap siklusnya, berarti pemahaman siswa Kelas XI-IPA 4 SMA Negeri 9 Kota Cirebon terhadap materi tersebut menunjukkan adanya peningkatan yang cukup signifikan. Hal ini dapat dilihat melalui diagram grafik.

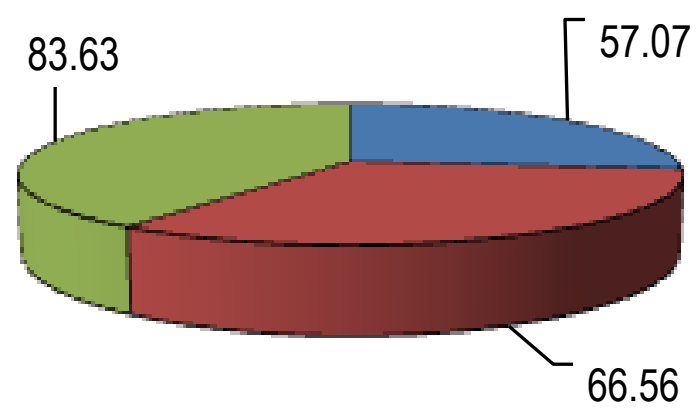

Gambar 4.1

Grafik Peningkatan Hasil Belajar Fisika Siswa Kelas XI-IPA 4

\section{Hasil observasi aktivitas belajar siswa}

Selama kegiatan proses pembelajaran Fisika pada materi "Kinematika Gerak Rotasi” di kelas XI-IPA 4 SMA Negeri 9 Kota Cirebon pada tiap siklusnya mengalami peningkatan, yaitu:

a. Siswa yang bisa menjawab pertanyaan atau permasalahan meningkat.

b. Siswa yang menyampaikan pendapat meningkat.

c. Siswa yang memperhatikan secara aktif meningkat.

d. Siswa yang mengajukan pertanyaan atau mengungkapkan permasalahan cukup meningkat.

e. Siwa yang bekerja dan belajar secara aktif.

1) Pada siklus I mencapai rata-rata : $48 \%$ (cukup baik)

2) Pada silus II mencapai rata-rata: $80 \%$ (baik)

\section{Hasil observasi kinerja guru}

Selama kegiatan pembelajaran Fisika pada materi "Kinematika Gerak Rotasi", terhadap kinearja guru menunjukkan kategori:

a. Pada siklus I menunjukkan rata-rata $49 \%$ (cukup baik).

b. Pada siklus II naik, dan menunjukkan rata -rata $94 \%$ (baik sekali).

Berdasarkan penjelasan di atas dapat disimpulkan bahwa hipotesis tindakan terbukti, yaitu dengan menerapkan Model Pembelajaran Explicit Intruction dapat 
Meningkatkan Pemahaman dan hasil belajar Fisika pada siswa Kelas XI-IPA 4 SMA Negeri 9 Kota Cirebon.

\section{Kesimpulan}

Dari hasil penelitian dan pembahasan, bahwa penerapan Model Pembelajaran Explicit Intruction dalam pembelajaran Fisika pada materi "Kinematika Gerak Rotasi" di Kelas XI-IPA 4 SMA Negeri 9 Kota Cirebon dapat disimpulkan:

1. Hasil belajar siswa dalam pembelajaran Fisika menunjukkan:

a. Hasil awal (Pra test) menunjukkan skor rata-rata: : 57.07.

b. Hasil pada siklus I naik menjadi skor rata-rata: 66.56 .

c. Hasil pada siklus II naik menjadi skor rata-rata: 83.63.

2. Aktivitas belajar siswa dalam kegiatan pembelajaran Fisika pada materi "Kinematika Gerak Rotasi" menunjukkan:

a. Siswa yang bisa menjawab pertanyaan atau permasalahan meningkat.

b. Siswa yang menyampaikan pendapat meningkat.

c. Siswa yang memperhatikan secara aktif meningkat.

d. Siswa yang mengajukan pertanyaan atau mengungkapkan permasalahan cukup meningkat.

e. Siwa yang bekerja dan belajar secara aktif.

1) Pada siklus I mencapai rata-rata : $48 \%$ (cukup baik)

2) Pada silus II mencapai rata-rata: $80 \%$ (baik).

3. Hasil Observasi Kinerja Guru dalam proses pembelajaran Fisika pada setiap siklusnya yaitu:

a. Pada siklus I menunjukkan rata-rata $49 \%$ (cukup baik).

b. Pada siklus II naik, dan menunjukkan rata -rata $94 \%$ (baik sekali).

4. hipotesis tindakan terbukti, yaitu dengan menerapkan Model Pembelajaran Explicit Intruction dapat Meningkatkan Pemahaman dan hasil belajar Fisika pada siswa Kelas XI-IPA 4 SMA Negeri 9 Kota Cirebon. 
Aris Supriyono

\section{BIBLIOGRAFI}

Arikunto, S., \& Suhardjono, S. (2006). Penelitian tindakan kelas. Jakarta: Bumi Aksara.

Harefa, A. R. (2013). Penerapan Model Pembelajaran Interaktif dengan Strategi Peta Konsep Pohon Jaringan di Kelas XI SMKN 1 Gunungsitoli. Jurnal Ilmiah IKIP Gunungsitoli, 168557.

Indrajit, D. (2009). Mudah dan Aktif Belajar Fisika. PT Grafindo Media Pratama.

Komalasari, K. (2010). Pembelajaran kontekstual konsep dan aplikasi. Bandung: Refika Aditama.

Komalawati, L. (2017). Peningkatan Hasil Belajar Fisik Melalui Pembelajaran Kooperatif Tipe GQGA (Giving Question And Getting Answer) Materi Fluida Statis Di Kelas XI MIPA 1 SMA Negeri 3 Cirebon Tahun Pelajaran 2015/2016. Syntax Literate; Jurnal Ilmiah Indonesia, 2(5), 103-111.

Suryono, S. (2012). Hakikat Pembelajaran Fisika. Diunduh Di Http://Ciget. Info. 